\title{
Pengetahuan dan Perilaku Ibu Rumah Tangga dalam Penggunaan Garam Beryodium Di Kelurahan Tosaren Kota Kediri
}

\author{
Dianti Ias Oktaviasari ${ }^{1) \otimes,}$, Fitara Amatul Firdausya ${ }^{2)}$ \\ ${ }^{1}$ Program Studi S1 Gizi, Fakultas Kesehatan, IIK Bhakti Wiyata Kediri \\ ${ }^{2}$ Program Studi S1 Kesehatan Masyarakat, Fakultas Teknologi dan Manajemen \\ Kesehatan, IIK Bhakti Wiyata Kediri \\ \ianti.oktaviasari@iik.ac.id
}

\begin{abstract}
ARTICLE INFO
$\begin{array}{ll}\text { Accepted } & : \text { 20 Mei } 2021 \\ \text { Approve } & \text { : 05 Juni 2021 } \\ \text { Publish } & : \text { 30 Juni 2021 }\end{array}$
\end{abstract}

\begin{abstract}
Iodine Deficiency Disorders (IDD) are a group of symptoms caused by the body being deficient in iodine for a long time. IDD is a serious problem and has a bad impact, so it needs good treatment, one of which is by iodization or fortification of all salts with potassium iodate (KOI3) or Universal Salt Iodization (USI). The national target has not yet reached the target of achieving USI by WHO (90\%) and the target coverage of households consuming iodised salt in 2020 as stated in the Achievement of Performance Indicators for Community Nutrition Development Activities for 2020-2024 is 82\%. The purpose of this study was to describe the knowledge and behavior of housewives in the use of iodized salt. This research is a cross sectional study. The population in this study were housewives in Kelurahan Tosaren, Kediri, who got 588. The sampling technique was taken by simple random sampling with the criteria of being able to fill out a google form and be willing to be a respondent. The sample size in this study was 85 housewives. The results showed that the knowledge of housewives about iodized salt in Kelurahan Tosaren, Kota Kediri was mostly good. The attitude towards the use of iodized salt most of the housewives agree with the use of iodized salt. The behavior of almost all housewives has used iodized salt for daily consumption. Good knowledge is in line with attitudes and behaviors in the use of iodized salt by housewives.
\end{abstract}

\section{Keywords: Iodized salt, knowledge, behavior, housewives}

\begin{abstract}
Abstrak
Gangguan Akibat Kekurangan Yodium (GAKY) merupakan sekumpulan gejala yang ditimbulkan karena tubuh kekurangan yodium dalam jangka waktu yang lama.GAKY merupakan masalah yang serius dan berdampak buruk sehingga perlu penanggulangan yang baik, salah satunya dengan iodisasi atau fortifikasi semua garam dengan kalium iodat (KOI3) atau Universal Salt Iodization (USI). Target cakupan nasional belum mencapai target capaian USI oleh WHO (90\%) dan target cakupan rumah tangga mengkonsumsi garam beriodium tahun 2020 yang tertuang dalam Capaian Indikator Kinerja Kegiatan Pembinaan Gizi Masyarakat Tahun 2020-2024 adalah 82\%. Tujuan
\end{abstract}


dari penelitian adalah mengetahui gambaran pengetahuan dan perilaku ibu rumah tangga dalam penggunaan garam beryodium.Penelitian ini merupakan penelitian cross sectional design. Populasi dalam penelitian ini adalah ibu rumah tangga di Kelurahan Tosaren Kota Kediri berjumlah 588. Teknik pengambilan sampel diambil dengan simple random samplingdengan kriteria dapat mengisi google form dan bersedia menjadi responden. Besar sampel pada penelitian ini adalah $85 \mathrm{ibu}$ rumah tangga.Hasil penelitian menunjukkan pengetahuan ibu rumah tangga terhadap garam beryodium di Kelurahan Tosaren Kota Kediri Sebagian besar sudah baik.Sikap terhadap penggunaan garam beryodium sebagian besar ibu rumah tangga setuju dengan penggunaan garam beryodium.Perilaku ibu rumah tangga hampir semua telah menggunakan garam beryodium untuk konsumsi sehari-hari.Pengetahuan yang baik selaras dengan sikap serta perilaku dalam penggunaan garam beryodium pada ibu rumah tangga.

\section{Kata Kunci: Garam beryodium, pengetahuan, perilaku, ibu rumah tangga}

\section{PENDAHULUAN}

Permasalahan yang dapat menghambat lajunya pembangunan kesehatan ialah Gangguan Akibat Kekurangan Yodium (GAKY), merupakan sekumpulan gejala yang ditimbulkan karena tubuh kekurangan yodium dalam jangka waktu yang lama. Pada umumnya masalah ini lebih banyak terjadi didaerah pegunungan, dimana makanan yang dikonsumsi tergantung pada produksi makanan yang berasal dari tanaman setempat dan tumbuh pada tanah dengan kondisi kadar yodium rendah (Adriani dan Wirjatmadi, 2012).

Yodium ialah zat gizi esensial berupa mineral mikro yang dibutuhkan sebanyak kurang lebih $0,00004 \%$ dari berat badan atau 15-23 mg. Yodium yang terkandung dalam, tubuh, kurang lebih $75 \%$ berada pada kelenjar tiroid, yang digunakan untuk sintesis hormon Tiroksin (T4) dan triiodotironin (T3) dan sebagian lainnya terdapat pada jaringan lain seperti kelenjar ludah, payudara, dan lambung serta didalam ginjal (Almatsier, 2009). Akibat dari defisiensi yodium yang berlangsung lama akan mengganggu fungsi kelenjar tiroid, yang secara perlahan menyebabkan kelenjar ini membesar sehingga menyebabkan gondok (Arisman, 2010).Kekurangan yodium dapat mempengaruhi perkembangan otak pada golden period, menyebabkan keterlambatan mental dan gangguan mental pada anak, serta dapat mempengaruhi perkembangan fisik, mental serta pengerasan pembuluh darah (Arisman, 2010; Almatsier, 2010; Sudargo, dkk, 2018).Kandungan yodium dalam makanan dapat susut akibat dari proses pemasakan yang 
salah dan menyebabkan absorbsi yodium rendah (Arisman, 2010).

GAKY merupakan masalah yang serius dan berdampak buruk sehingga perlu penanggulangan yang baik, salah satunya dengan iodisasi atau fortifikasi semua garam dengan kalium iodat (KOI3) atau Universal Salt Iodization (USI).Tujuan kegiatan ini agar semua garam yodium yang dikonsumsi masyarakat mengandung yodium minimal 30 ppm.Data Riskesdas (2013) menunjukkan secara nasional cakupan rumah tangga yang mengonsumsi garam dengan kandungan cukup iodium 77,1\%. Angka cakupan meningkat dibandingkan dengan cakupan pada tahun 2007, yakni 62,30\% (Riskesdas, 2007). Target capaian di Jawa Timur menunjukkan jumlah rumah tangga yang mengkonsumsi garam dengan kandungan iodium cukup 75,4\%, kandungan rendah $13,7 \%$ dan $10,9 \%$ rumah tangga yang mengkonsumsi garam tanpa kandungan iodium (Riskesdas, 2013). Target cakupan tersebut belum mencapai target capaian USI oleh WHO adalah 90\% dan target cakupan rumah tangga mengkonsumsi garam beriodium tahun 2020 yang tertuang dalam Capaian Indikator Kinerja Kegiatan Pembinaan Gizi
Masyarakat Tahun 2020-2024adalah 82\% (WHO, 2007; Kemenkes RI, 2020).Uraian diatas menjadi dasar peneliti melakukan penelitian dengan tujuan mengetahui gambaran pengetahuan dan perilaku ibu rumah tangga dalam penggunaan garam beryodium.

\section{METODE}

Penelitian ini merupakan penelitian cross sectional design. Penelitian dilaksanakan di Kelurahan Tosaren Kota Kediri. Penelitian dilaksanakan pada bulan Januari sampai dengan Februari 2021. Populasi dalam penelitian ini adalah ibu rumah tangga di Kelurahan Tosaren Kota Kediri berjumlah 588. Teknik pengambilan sampel diambil dengan simple random sampling dengan kriteria dapat mengisi google form dan bersedia menjadi responden. Besar sampel pada penelitian ini dihitung menggunakan Rumus Slovin sebesar 85 ibu rumah tangga. Data dikumpulkan dengan metode pengisian kuesioner secara daring (dengan google form) karena pelaksanaan penelitian di masa pandemi. Data yang dikumpulkan dari kuesioner antara lain data karakteristik responden, pengetahuan terdiri dari 11 
pertanyaan, sikap terdiri dari 8 pertanyaan dan perilaku terdiri dari 10

\section{HASIL DAN PEMBAHASAN}

pertanyaan yang diisi oleh responden mengenai penggunaan garam beryodium.

Variabel pada penelitian ini adalah pengetahuan, sikap dan perilaku penggunaan garam beryodium. Pengolahan dan analisis data dilakukan secara deskriptif untuk memperoleh data gambaran pengetahun, sikap dan perilaku penggunaan garam beryodium.
Hasil penelitian menunjukkan bagaimana gambaran perilaku ibu rumah tangga dalam penggunaan garam beryodium. Responden adalah $85 \mathrm{ibu}$ rumah tangga dengan rentang usia paling banyak 26-35 tahun dan pendidikan sebagian besar SLTA.Data karakteristik responden dapat dilihat pada tabel 1 .

Tabel 1.Karakteristik Responden dalam Penggunaan Garam Beryodium di Kelurahan Tosaren Kota Kediri Tahun 2021

\begin{tabular}{ccc}
\hline \multirow{2}{*}{ Karakteristik } & \multicolumn{2}{c}{ Tosaren Kota Kediri Tahun 2021 } \\
\cline { 2 - 3 } & $\mathbf{N}$ & \% \\
\hline Umur & 9 & 10,59 \\
$20-25$ & 51 & 60,00 \\
$26-35$ & 25 & 29,41 \\
$36-45$ & & \\
& 3 & 3,53 \\
Pendidikan & 9 & 10,59 \\
SD & 41 & 48,2 \\
SMP & 32 & 37,65 \\
SMA & & \\
Akademi/ Perguruan tinggi & & \\
\hline
\end{tabular}

Tabel 2 menunjukkan pengetahuan responden terhadap garam beryodium. Pengetahuan terhadap garam beryodium meliputi pernah tidaknya mendengar tentang garam beryodium, sumber informasi mengenai garam beryodium, manfaat garam beryodium, cara pemilihan garam beryodium, cara penyimpanan garam beryodium, dan alasan tempat penyimpanan garam beryodium harus tepat. Selain hal tersebut pengetahuan juga mencakup kandungan iodium yang tertulis pada kemasan dan cara pengujian kandungan yodium pada garam. 
Tabel 2. Pengetahuan Responden dalam Penggunaan Garam Beryodium di Kelurahan Tosaren Kota Kediri Tahun 2021

\begin{tabular}{|c|c|c|}
\hline \multirow[t]{2}{*}{ Kategori Pengetahuan } & \multicolumn{2}{|c|}{ Jumlah } \\
\hline & $\mathbf{N}$ & $\%$ \\
\hline \multicolumn{3}{|l|}{$\begin{array}{l}\text { 1. Mengetahui istilah garam } \\
\text { beryodium }\end{array}$} \\
\hline Ya & 85 & 100 \\
\hline Tidak & 0 & 0 \\
\hline \multicolumn{3}{|l|}{$\begin{array}{l}\text { 2. Sumber informasi tentang garam } \\
\text { beryodium }\end{array}$} \\
\hline Petugas Kesehatan & 54 & 63,53 \\
\hline Kader & 17 & 20 \\
\hline Media Lainnya & 14 & 16,47 \\
\hline \multicolumn{3}{|l|}{ 3. Manfaat garam beryodium } \\
\hline Mencegah penyakit gondok & 81 & 95,29 \\
\hline Sebagai penyedap makanan & 3 & 3,53 \\
\hline Tidak tahu & 1 & 1,18 \\
\hline \multicolumn{3}{|l|}{$\begin{array}{l}\text { 4. Cara pemilihan garam } \\
\text { beryodium yang baik }\end{array}$} \\
\hline Garam yang dikemas dan bermerk & 85 & 100 \\
\hline $\begin{array}{l}\text { Garam yang dikemas dan tidak } \\
\text { bermerk }\end{array}$ & 0 & 0 \\
\hline $\begin{array}{l}\text { Garam tanpa kemasan } \text { (garam } \\
\text { curah) }\end{array}$ & 0 & 0 \\
\hline \multicolumn{3}{|l|}{$\begin{array}{l}\text { 5. Cara penyimpanan garam } \\
\text { beryodium yang benar }\end{array}$} \\
\hline $\begin{array}{l}\text { Pada wadah tertutup rapat dan } \\
\text { tidak dekat dengan hawa panas }\end{array}$ & 84 & 98,82 \\
\hline & 1 & 1,18 \\
\hline $\begin{array}{l}\text { 6. Alasan penyimpanan garam } \\
\text { beryodium yang tepat }\end{array}$ & & \\
\hline $\begin{array}{l}\text { Supaya kadar iodium tidak } \\
\text { mengalamipenguapan/kerusakan }\end{array}$ & 80 & 94,12 \\
\hline Supaya garamnya & & \\
\hline kering/tidakbasah & 5 & 5,88 \\
\hline nya t & 0 & 0 \\
\hline \multirow[t]{2}{*}{$\begin{array}{l}\text { 7. Kandungan yodium } \\
\text { kemasan garam } \\
\text { 30-80 ppm } \\
\text { 10-30 ppm } \\
\text { Tidak tahu }\end{array}$} & & \\
\hline & 52 & 61,18 \\
\hline
\end{tabular}




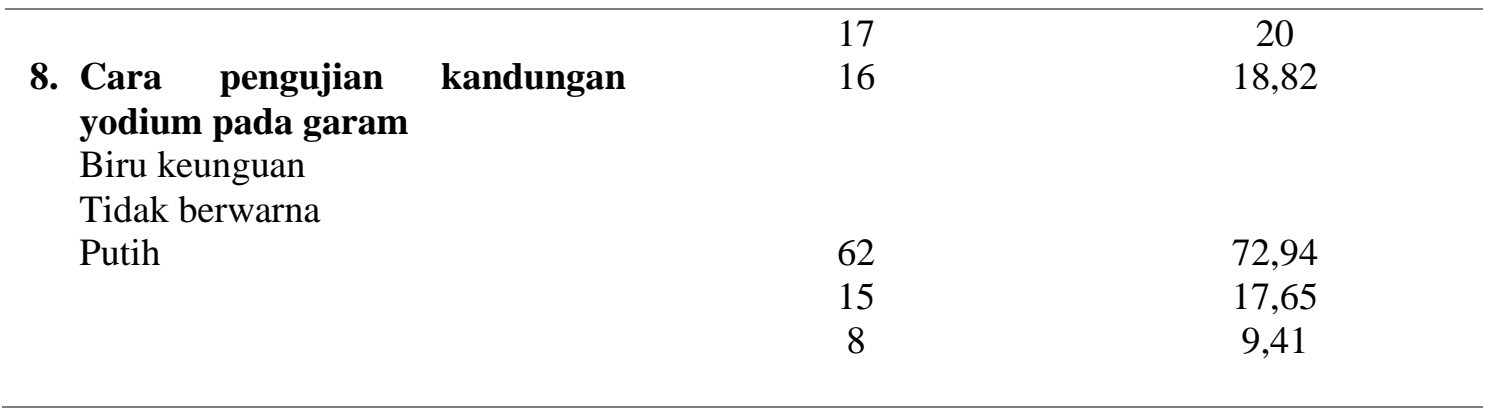

Tabel 3 menunjukkan tingkat mempunyai pengetahuan yang baik dan pengetahuan responden terhadap garam $11,09 \%$ responden dengan pengetahuan beryodium. Hasil penelitian kurang.

menunjukkan bahwa $88,91 \%$ responden

Tabel 3. Tingkat Pengetahuan Responden terhadapPenggunaan Garam Beryodium di Kelurahan Tosaren Kota Kediri Tahun 2021

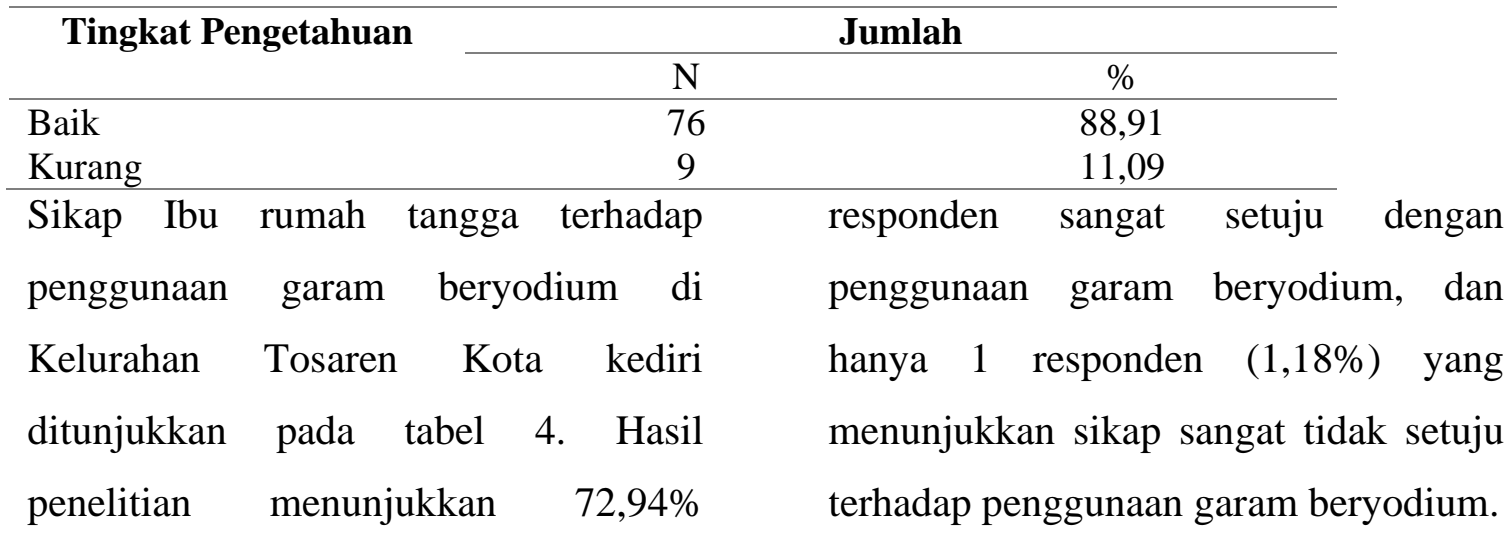

Tabel 4. Sikap Responden dalam Penggunaan Garam Beryodium di Kelurahan Tosaren

\begin{tabular}{lcc} 
& \multicolumn{3}{c}{ Kota Kediri Tahun 2021 } \\
\cline { 2 - 3 } \multicolumn{1}{c}{ Karakteristik } & $\mathrm{n}$ & Jumlah \\
\hline Sangat Setuju & 62 & 72,94 \\
Setuju & 16 & 18,82 \\
Tidak Setuju & 6 & 7,06 \\
Sangat Tidak Setuju & 1 & 1,18 \\
& & \\
\hline
\end{tabular}

Perilaku ibu rumah tangga dalam penggunaan garam beryodium di

Kelurahan Tosaren Kota Kediri ditunjukkan pada tabel 5. Hasil penelitian menunjukkan bahwa
Sebagian besar responden (98.82\%) telah menggunakan garam beryodium dan hanya 1 responden $(1,18 \%)$ yang tidak menggunakan garam beryodium untuk konsumsi sehari-hari. 
Tabel 5. Perilaku Responden dalam Penggunaan Garam Beryodium di Kelurahan Tosaren Kota Kediri Tahun 2021

\begin{tabular}{lcc}
\hline \multicolumn{1}{c}{ Karakteristik } & \multicolumn{3}{c}{ Jumlah } \\
\cline { 2 - 3 } & G & $\%$ \\
\hline $\begin{array}{l}\text { Menggunakan } \\
\text { beryodium }\end{array}$ & 84 & 98,82 \\
$\begin{array}{l}\text { Tidak menggunakan garam } \\
\text { beryodium }\end{array}$ & 1 & 1,18 \\
\hline
\end{tabular}

\section{A. Tingkat Pendidikan Responden}

Hasil penelitian menunjukkan sebagian besar jenjang Pendidikan responden adalah SMA dan terbesar kedua adalah Akademi/ Perguruan tinggi.Faktor pendidikan adalah salah satu faktor yang mempengaruhi pengetahuan dan sikap (Notoatmojo, 2003).Tingkat Pendidikan ibu sejalan dengan tingkat pengetahuan ibu mengenai garam beryodium.Hal tersebut sesuai dengan penelitian Nadimin (2015) yang menyatakan bahwa tingkat pendidikan pada ibu dan kepala keluarga yang tinggi lebih cenderung menggunakan garam beryodium.Penelitian juga sejalan dengan Rini, dkk (2017) yang menyatakan bahwa ada hubungan signifikan antara pendidikan ibu dengan tingkat konsumsi garam beryodium pada ibu rumah tangga.

\section{B. Pengetahuan Responden dalam penggunaan garam beryodium}

Berdasarkan penelitian yang telah dilakukan didapatkan hasil bahwa sebagian besar responden telah memiliki pengetahuan yang baik mengenai garam beryodium, dimana responden telah mampu menjawab pertanyaan dengan benar sebesar $\geq 75 \%$ (Budiman, 2013). Pengetahun responden ini telah mencapai tahap dimana pengetahuan yang baik diikuti dengan sikap dan perilaku dalam penggunaan garam beryodium. Ibu yang memiliki pengetahuan baik memiliki kecenderungan menggunakan garam beryodium untuk keperluan seharihari. Sebaliknya, ibu yang pengetahuannya kurang cenderung tidak menggunakan garam beryodium dalam rumah tangganya sebab mereka belum tahu apa saja manfaat penggunaan garam beyodium(Auliyanah,2010).

Hasil penelitian sesuai dengan penelitian oleh Noviani (2007) menyatakan bahwa umumnya pengetahuan dapat mempengaruhi 
sikap dari diri seseorang dan tindakan seseorang dalam kehidupan sehari-hari. Tingkat pengetahuan ibu tentang garam beryodium yang baik juga dapat menunjang ibu dalampenggunaan garam beryodium untuk sehari- hari.

\section{C.Sikap Responden dalam} penggunaan garam beryodium

Sikap ibu rumah tangga terhadap garam beryodium merupakan suatu respon mereka terhadap penggunaan garam beryodium yang membuatnya memiliki kecenderungan untuk berespon sangat setuju atau sangat tidak setuju terhadap hal tersebut (Notoatmodjo, 2014).Hasil penelitian menunjukkan bahwa Sebagian besar responden bersikap setuju dengan penggunaan garam beryodium untuk sehari-hari.Sesuai dengan teori yang dikemukakan Lawrence Green dalam Notoatmodjo (2014) menyatakan bahwa salah satu perilaku kesehatan seseorang dipengaruhi oleh faktor predisposisi yaitu umur, pekerjaan, pendidikan, pengetahuan dan sikap.Salah satu dari empat alasan pokok yang menyebabkan seseorang berperilaku adalah sikap. Sikap ini dapat diperoleh dari pengalaman sendiri atau dari orang lain yang paling dekat (Notoatmodjo, 2007).

\section{Perilaku Responden dalam penggunaan garam beryodium} Hasil penelitian menunjukkan bahwa hampir seluruh responden telah menggunakan garam beryodium untuk keperluan sehari-hari, hanya 1 responden yang masih belum menggunakan garam beryodium. Data penggunaan garam beryodium selain didapatkan dari hasil jawaban kuesioner juga dari foto yang dikirimkan oleh responden mengenai kemasan garam yang digunakan untuk rumah tangga. Hasil penelitian juga menunjukkan Sebagian besar pengetahuan responden baik dan sikap setuju terhadap penggunaan garam beryodium. Hal tersebut sejalan dengan penelitian Auliyanah (2010) bahwa perilaku dipengaruhi terhadap bagaimana sikap ibu rumah tangga terhadap penggunaan garam beryodium dan dipengaruhi oleh pengetahuan ibu. Sikap merupakan tanggapan yang akan menjasi perilaku jika dipengaruhi oleh keyakinan bahwa perilaku tersebut akan menghasilkan seuai dengan yang diinginkan ataupun tidak 
Pengetahuan ibu yang baik akan membuka wawasan ibu terhadap informasi tentang garam beryodium yang selanjutnya diterapkan dalam perilaku sehari-hari.

\section{KESIMPULAN}

Dari hasil penelitian dapat disimpulkan bahwa pengetahuan ibu rumah tangga terhadap garam beryodium di Kelurahan Tosaren Kota Kediri Sebagian besar sudah baik.Sebagian besar ibu rumah tangga setuju dengan sikap terhadap penggunaan garam beryodium.Perilaku ibu rumah tangga hampir semua telah menggunakan garam beryodium untuk konsumsi sehari-hari.Pengetahuan yang baik selaras dengan sikap serta perilaku dalam penggunaan garam beryodium pada ibu rumah tangga, sehingga diharapkan manfaat dari fortifikasi garam beryodium dapat meningkatkan kualitas hidup masyarakat.

\section{DAFTAR PUSTAKA}

Adriani M, Wirjatmadi B. 2012. Pengantar Gizi Masyarakat. Jakarta :Kencana Prenada Media Group

Almatsier, Sunita. 2009. Prinsip Dasar Imu Gizi.Jakarta: PT Gramedia Pustaka Utama

Arisman,MB. 2010. Gizi dalam Daur Kehidupan. Jakarta: EGC

Aulinayah, Anna.2010. Faktor-faktor yang Berhubungan dengan
Penggunaan Garam Beryodium pada rumah Tangga di Desa Bukit Tinggi Kecamatan Gantarang Kabupaten Bulukumba SkripsiUIN Alauddin Makassar

Budiman dan Riyanto. 2013. Kapita Selekta Kuesioner: Pengetahuan dan Sikap dalam Penelitian Kesehatan. Jakarta: Penerbit Salemba Medika

Kemenkes RI. 2013. Riset Kesehatan Dasar (RISKESDAS) Tahun 2013.Jakarta: Kementerian Kesehatan RI

Kemenkes RI. 2020. Rencana Aksi Kegiatan Direktorat Gizi Masyarakat Tahun 20202025.Jakarta:Kementerian Kesehatan RI

Nadimin.2015. Hubungan Tingkat Pendidikan dengan Penggunaan Garam Beryodium Tingkat Rumah Tangga di Sulawesi Selatan. Jurnal MKMI. Desember 2015, Hal: 235-240.

Notoatmodjo, Soekidjo. 2003. Pendidikan dan Perilaku Kesehatan. Jakarta: Rineka Cipta

Notoatmodjo, Soekidjo. 2007. Promosi Kesehatan Dan Ilmu Perilaku. Jakarta: Rineka Cipta

Notoatmodjo, Soekidjo. 2014. Ilmu Perilaku Kesehatan. Jakarta: Rineka Cipta

Noviani, Ismalia. 2007. Analisis Faktorfaktor yang Berhubungan dengan Penggunaan Garam Beryodim di Rumah Tangga di Desa Sumur Gede Kec. Godong Kab. Grobogan Skripsi Universitas Negeri Semarang

Rini, H.M., dkk. 2017. Faktor-Faktor Yang Mempengaruhi Tingkat Konsumsi Garam Beryodium Pada Ibu Rumah Tangga di Desa Gembong Kecamatan Gembong Kabupaten Pati. Jurnal 
Kedokteran Diponegoro. Vol. 6, No. 2, Hal: 632-644.

Sudargo, dkk. 2018. Defisiensi Yodium,

Zat

Besi,

dan

Kecerdasan.Yogyakarta: Gajah Mada University Press

WHO. 2007. Assessment of Iodine

Deficiency Disorders and Monitoring Their Elimination: A Guide For Programme Managers. $(3 r d$ ed). USA: World Health Organization 